\title{
Avis de publication : Statistiques canadiennes sur le cancer 2013
}

Vient de paraître!

Les Statistiques

canadiennes sur le cancer 2013 ont été

publiées le 29 mai 2013.

Cette publication annuelle sur l'incidence, la mortalité, la survie et les autres aspects du fardeau du cancer arbore une nouvelle présentation et un nouveau contenu.

Téléchargez ou imprimez cette dernière édition ou les éditions précédentes des Statistiques canadiennes sur le

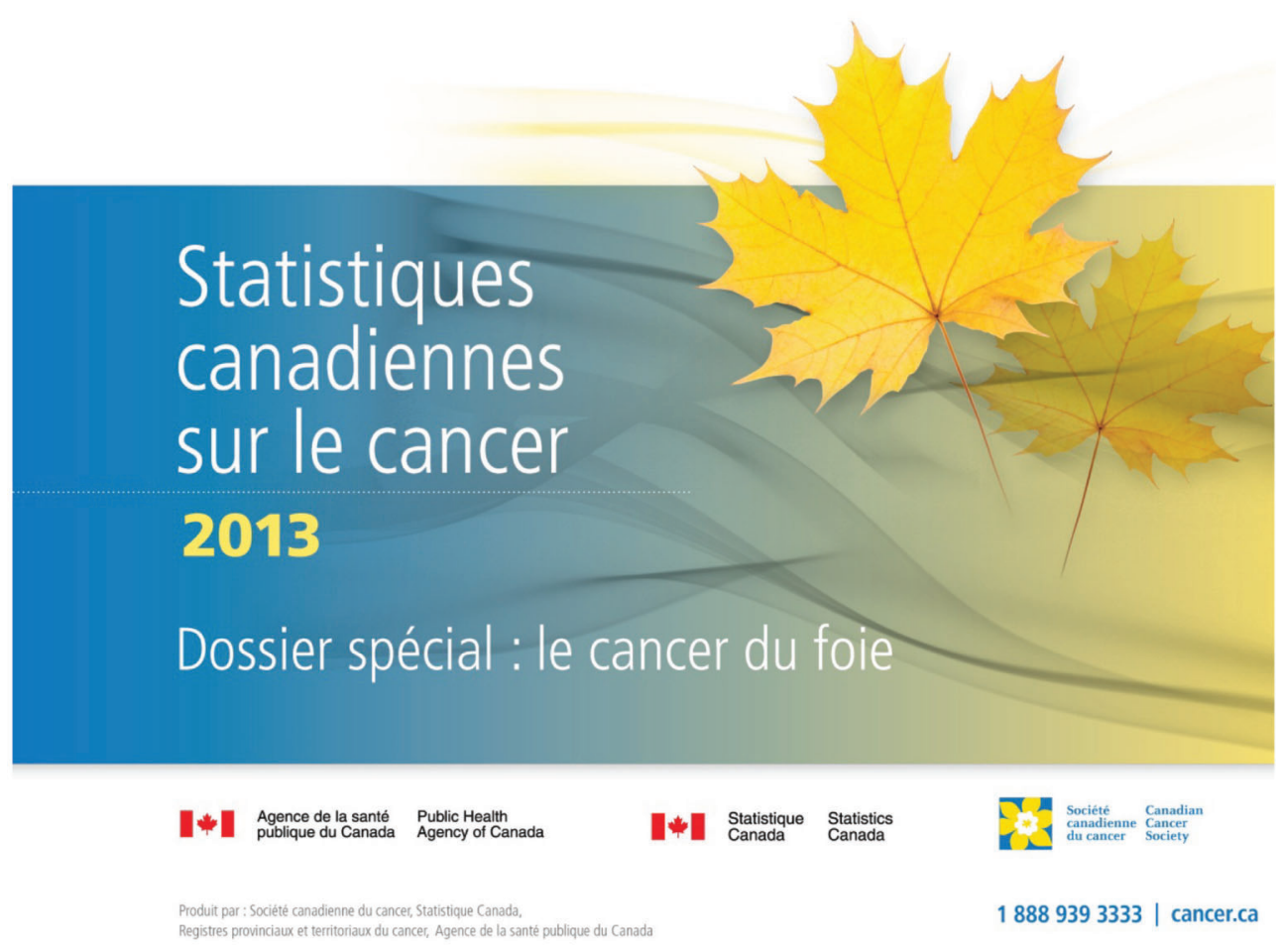
cancer à partir de la page :

cancer.ca/statistiques 